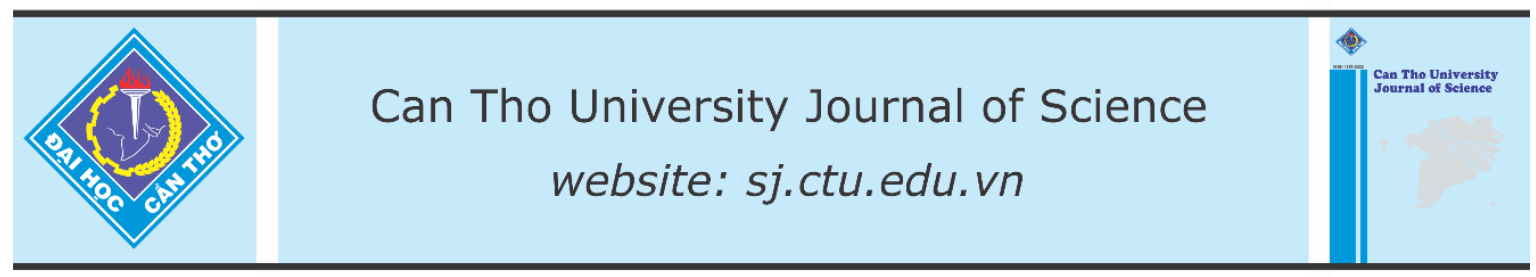

DOI: 10.22144/ctu.jen.2020.004

\title{
Teachers' professional development as a tool to enhance institutional quality: Current practices at a center for foreign languages
}

\author{
Luu Nguyen Quoc Hung* \\ Center for Foreign Languages, Can Tho University, Vietnam \\ *Correspondence: Luu Nguyen Quoc Hung (email: Inqhung@ctu.edu.vn)
}

\section{Article info.}

Received 22 Nov 2019

Revised 24 Mar 2020

Accepted 31 Mar 2020

\section{Keywords}

Effectiveness, performance, professional development, quality

\begin{abstract}
In this incredibly challenging and complex world, many teaching professionals require continuous learning and support, or professional development. Teachers are always recognized as key players in the education system, and therefore professional development of these teachers is crucial if the quality of education is to be enhanced. At a center for foreign languages in Vietnam, professional development activities are always encouraged. Annually, teachers of every level are required to attend certain workshops and structured training and learning sessions, and their participation in these activities are necessary for their performance evaluation related to teaching contracts and pay for performance. The current study has been undertaken with 51 teachers of English at the Center for Foreign Languages in Can Tho University, Vietnam. An online survey was administered to assess the teachers' perceptions of the effectiveness of the professional development activities and of the influence of these activites on quality of education. After three years of implementation, these programs of professional development have gained initial positive results. There is an increasing number of teachers who have gained necessary language competency and teaching qualifications. Through practical and effective activities such as implementing a new set of curriculum materials, professional discussions, attending workshops or seminars, teachers have taken up opportunities for further academic growth and consequently could enhance the quality of education. From the current practices, there are important implications. When educational leaders and managers need to enhance the institutional quality, they should provide appropriate teachers' professional development programs.
\end{abstract}

Cited as: Hung, L.N.Q.H., 2020. Teachers' professional development as a tool to enhance institutional quality: Current practices at a center for foreign languages. Can Tho University Journal of Science. 12(1): 30-36.

\section{INTRODUCTION}

Quality of education has become one of the central issues in the recent educational reforms in the world, and the success of any education system depends on the quality of teachers. Teachers are one of the most important components of any educational system. A World Bank paper commented that 'a high quality and well-motivated teaching staff and a supportive professional culture are essential in building excellence' (World Bank, 1994). Few would argue 
against the view that motivated staff are a central resource for the success of an organization, and thus attention needs to be given to teachers' professional development (Blackwell and Blackmore, 2003). Professional development is deemed as an essential component of the work environment, including the activities and programs either formal or informal that help teachers learn about responsibilities, develop required skills and competencies necessary to accomplish both individual and institutional goals and purposes (Marcelo, 2009).

The Center for Foreign Languages, Can Tho University (hereafter referred to as the Center or CFL) is committed to optimizing opportunities to improve teachers' knowledge and skills at all levels in the workplace. The development of academic staff is a joint responsibility shared by the individual staff member and the academic administrator of the Center. Every year, all teachers are required to sign a teaching contract which articulates their job description and responsibility at their level. Individual teachers are primarily responsible for developing and following their own professional development plans together with the Center's workload. Each academic staff member is to ensure that the portfolio of activities they have selected can respond to their learning and development needs effectively and efficiently. These practices of professional development are expected to improve both individual teacher's growth and the Center's performance quality. Professional development of teachers generally is a broad and diverse field of knowledge. While most studies on teachers' professional development have been centered in institutional settings, primarily in public universities, it appears that few studies have been done in Vietnamese context, especially in the context of English language centers. The aim of this small-scale study is to examine current practices of professional development with a group of teachers at the Center with the aim to identify the most common and effective activities for professional development and the influence of these activities on the Center's quality management.

\section{LITERATURE REVIEW}

\subsection{Teachers' professional development and its purposes}

Professional development refers to many types of educational experiences related to an individual's work. The professional development of teachers is regarded as an individual and collective process that should be accomplished in the workplace of the teacher, that is, the school (Marcelo, 2009). In many countries, the role and function of schools are changing and so are expected of teachers. Teachers of the $21^{\text {st }}$ century are asked to teach in increasingly multicultural classrooms, to place greater emphasis on integrating students with special learning needs in their classrooms, to make more effective use of information and communication technologies for teaching, and to create students with soft skills (Jan, 2017). From OECD's perspective (2009), professional development is defined as "activities that develop an individual's skills, knowledge, expertise and other characteristics as a teacher". No matter how good pre-service training for teachers is, it cannot be expected to prepare teachers for all the challenges they will face throughout their careers. Institutions therefore need to provide teachers with opportunities for in-service professional development in order to maintain a high standard of teaching.

According to OECD (2009), the development of teachers can serve a number of objectives including updating individual's knowledge of a subject in light of recent advances in the area and updating individual's skills, attitudes and approaches in terms of the development of new teaching techniques and new educational research. Professional development activites also enable individuals to apply changes made to curricula or other aspects of teaching practice and exchanging information and expertise among teachers. More importantly, weaker teachers are expected to become more effective, thanks to their developing and appling new strategies concerning the curriculum and other aspects of teaching practice.

\subsection{Activities of professional development}

Professional development refers to a wide range of activities that are intended to improve teacher practice. Teachers' professional development may be different in various contexts, and these programs differ from one university to another and often contain formal and informal programs. Formal programs include conferences, workshops, seminars, short-term training programs, and informal programs may include discussions among colleagues, self-directed learning, and non-formal education. The followings are eight common activities for academic staff development as suggested in a handbook for continuing professional development prepared by English Agenda, British Council (2012).

- Workshops or training activities: These activities are a good way to stimulate teachers' teaching with new classroom ideas and reflection on practice. 
- Conferences or seminars: Attending these activities, teachers can meet and talk with other teachers and learn from sessions given by experts, and more importantly, when teachers are experienced and confident, giving a presentation is a way to share teachers' experience with colleagues and is a good professional development activity.

- Qualification programs: Studying for a qualification is a very effective professional development activity. There is always something more to learn at different stage of the teachers' profession.

- Network: Networking with other teachers is one of the most stimulating ways to discuss common issues and share experiences. Attending meetings and social events in educational settings is a great way to connect with people in the field.

- Material development: Involvement with teaching materials is a relevant way of developing. Selecting or implementing a new set of curriculum materials can be a powerful form of professional development. Teachers can also start to develop their own materials to meet the needs of their own learners and their own teaching styles.

- Research: Small-scale classroom action research can help teachers find out more about classroom processes and so develop their professional knowledge and skills.

- Mentoring: Learning from a more experienced colleague is an invaluable way to gain insight into teaching. Similarly, with an experienced teacher, it is a good developmental activity to mentor a less experienced colleague.

- Observations: Being observed and getting feedback from a trusted colleague can give teachers a fresh perspective and help teachers identify areas teachers may develop. Beside in-class observations, 'ghost observation' is also effective when a teacher is not confident about someone sitting in the class. Then teachers can talk with colleagues about the lesson they are going to teach. The colleagues do not observe the lessons, but they can discuss the lessons and the areas of development.

\subsection{Teachers' professional development and institutional quality}

Teacher is one of the most important elements in education. The quality of education is largely determined by the teacher's quality (Gore et al., 2017). Institutional quality has been described as "the success with which an institution provides educational environments which enable students effectively to achieve worthwhile learning goals including appropriate academic standards (Gordon and Partington, 1993 cited in Rowley, 1996). In raising the education standards and quality, efforts towards enhancing teacher professionalism for ensuring quality of the teacher and teaching quality become the important issue in the education policy production (Jusuf, 2005). To improve the quality and the competence of the teachers, there should be some concrete activities. Activities of professional development such as mentoring, attending workshops and seminars, training, and participating in action research are certainly very important to enhance both teachers' teaching performance and their quality education (Nagoba and Mantri, 2015).

\section{THE STUDY}

\subsection{The CFL and its policy of professional development}

The Center was established in 1991, under the management of Can Tho University and has been providing courses of English, French, Chinese, Japanese, Korean and Vietnamese to the community for the past consecutive 28 years. The number of teachers has almost doubled in the early decade of the $21^{\text {st }}$ century when the need of foreign language teaching and learning has rapidly increased. The challenge for this fast growth is that the Center has to guarantee both the quantity and the quality of the staff. The Center recognizes its greatest asset to achieve its strategic objectives is the academic staff and that any effort towards improving their contribution is of great importance.

The Center is committed to providing an environment that is conductive to effective performance and promotes development opportunities for all staff. Every academic staff member is expected to actively engage in professional development activities that will enhance their capabilities not only for satisfactory performance in their current role but also for future advancement.

At the start of every academic year, the academic administrators propose and discuss teaching plans with teachers, which inform teaching skills, types of class as well as other extracurricular activities. Teachers are also required to propose their specific professional development plan which sets out individual learning goals on a short-term or long-term basis, and give clear steps for achieving them. Teachers and administrators should share similar perspectives about effective staff development programs. 
The current study has been undertaken with all teachers of English at the Center of Foreign Languages in Can Tho University. These teachers are contract teachers, who teach mostly in English classes in the evenings and at weekends.

\subsection{Methods of the study}

In this study, the descriptive survey design was employed, in which questionnaires are distributed to all the teachers in the particular language center. The survey method is appropriate as it entails the development of a questionnaire based on the literature review of teachers' professional development.

\subsection{The questionnaire}

The teaching staff were invited to respond to a questionnaire. They were asked to select 'yes' or 'no' for whether or not they participate in the eight common activities of professional development. Also, they reported the extent of impact of these activities on their professional development. There are four levels of influence from 'no impact', 'small impact', 'moderate impact' and 'large impact'.

\subsection{The participants}

The surveys were handed out to all teachers of the Center. There were 51 out of 74 (68.9\%) respondents completing the survey, indicating the eight most typical professional development activities they attended during the last 12 months. Most teachers are young in their career and they are within the age range of 25 to 50 years.

\section{RESULTS AND DISCUSSIONS}

The detailed analysis of the survey is presented in Table 1. The results and discussions have been organized into eight sections of the common activities of teachers' professional development and their influence on teachers. Generally, over 50 percent of the teachers in this study indicated that they participated in a certain activity of professional development for the past year. The most common acvitity was attending training courses or workshops and the least common activity was participating in research.

Table 1: Types of professional development activity and its influence

\begin{tabular}{|c|c|c|c|c|c|c|}
\hline \multirow[b]{2}{*}{ Activities } & \multicolumn{2}{|c|}{ Participation (\%) } & \multicolumn{4}{|c|}{ Impact $(\%)$} \\
\hline & Yes & No & $\begin{array}{r}\text { No im- } \\
\text { pact }\end{array}$ & $\begin{array}{r}\text { Small } \\
\text { impact }\end{array}$ & $\begin{array}{r}\text { Moderate } \\
\text { impact }\end{array}$ & $\begin{array}{r}\text { Large } \\
\text { impact }\end{array}$ \\
\hline $\begin{array}{l}\text { Attending courses/workshops (e.g. on } \\
\text { subject matter or methods and/or other } \\
\text { education-related topics) }\end{array}$ & 100 & - & - & 3.9 & 49.0 & 47.1 \\
\hline $\begin{array}{l}\text { Attending observations (being observed } \\
\text { and getting feedback from a trusted col- } \\
\text { league can give you a fresh perspective } \\
\text { on your teaching) }\end{array}$ & 86.3 & 13.7 & - & 2.3 & 56.8 & 40.9 \\
\hline $\begin{array}{l}\text { Mentoring (learning from a more expe- } \\
\text { rienced colleague. }\end{array}$ & 84.3 & 15.7 & 2.3 & 4.6 & 41.9 & 51.2 \\
\hline Developing teaching materials & 78.4 & 21.6 & - & 2.5 & 47.5 & 50 \\
\hline $\begin{array}{l}\text { Attending education conferences or } \\
\text { seminars (where teachers and/or re- } \\
\text { searchers present their research results } \\
\text { and discuss educational problems }\end{array}$ & 74.5 & 25.5 & - & 10.5 & 57.9 & 31.6 \\
\hline $\begin{array}{l}\text { Participating in a network of teachers } \\
\text { formed specifically for the professional } \\
\text { development of teachers }\end{array}$ & 64.7 & 35.3 & 3.0 & 9.1 & 51.5 & 36.4 \\
\hline $\begin{array}{l}\text { Attending a qualification program (e.g. } \\
\text { degree program) }\end{array}$ & 54.9 & 45.1 & 7.1 & 3.6 & 46.4 & 42.9 \\
\hline $\begin{array}{l}\text { Participating in individual or collabora- } \\
\text { tive research on a topic of interest to } \\
\text { you professionally }\end{array}$ & 52.9 & 47.1 & 11.1 & - & 48.2 & 40.7 \\
\hline
\end{tabular}




\subsection{About attending courses and workshops}

Of the eight listed activities of professional development, all 51 teachers indicated "Attending courses/workshops (e.g. on subject matter or methods and/or other education-related topics)" as the most common activity they attended (see Table 1). It is no surprising that workshops and formal training courses are very effective. The Center organizes monthly workshops, and the presenters are colleagues who can share teaching techniques or discuss common problems or issues in their teaching. In addition, the Center encourages and provides financial supports to the staff members to attend formal workshops organized by VUS TESOL, VietTESOL, SEAMEO RETRAC (Southeast Asian Ministers of Education Organization Regional Training Center) or by popular publishers such as Cambridge University Press, Oxford University Press, Macmillan Education, or Dai Truong Phat Education.

\subsection{Attending observations}

As shown in Table 1, about the activity of "Attending observations (being observed and getting feedback from a trusted colleague can give you a fresh perspective on your teaching), over 86 percent of teachers in this study indicated that this activity had significant influence on their performance. Being observed in the classroom can rattle any teacher's nerves, but class observation can yield its greatest benefits when used as a means of sharing instructional techniques and ideologies between and among teachers. For the past three years, the Center has applied peer observation called "Good demonstration lesson" in which each teacher can plan a lesson and teach the lesson to a group of colleagues. Effective teaching strategies or techniques, new ideas or problem-solving experiences can be presented and discussed.

\subsection{Mentoring}

Mentoring is also a practical and useful activity that over 84 percent of the teachers participated in for the past year. It is also important to note that the highest percentage of the teachers $(51.2 \%)$ reported that this activity had large impact on their performance. It is possible that about a third of academic staff are young teachers, who really need induction or professional orientation in their early career. These induction activities enable the new academics to have an introduction to the policies, people, practices and system of the Center. Mentoring is important, not only because of the knowledge and skills the academic staff member can learn from mentors, but also because mentoring can provide professional socialization and personal support to facilitate individual success (Mizell, 2010). At the Center, experienced or specialist teachers are a source of knowledge for novice teachers or teachers wishing to specialize in a new subject matter.

\subsection{Developing teaching materials}

One common activity received much attention and quite high level of participation is developing teaching materials. As indicated in Table 1, nearly 80 percent of the participants participated in this activity and agreed that it had much effect on their professional development. Teaching materials generally refer to a number of teacher resources. Ideally, the teaching materials will be tailored to the content to support student learning and increase student success. It is certain that teachers can learn and develop teaching skills through their creating or modifying teaching materials. At the Center, teachers are encouraged to develop teaching materials such as worksheets, game activities or test items. The teachers' contributions are recognized in annual teacher evaluations.

\subsection{Attending education conference or seminars}

Attending conferences or seminars is also a popular activity. Thirty-eight (74.5\%) of the participants indicated the positive impact of these activities on their professional development. By attending professional conferences, teachers can learn from others and improve their own skills and knowledge about the field. Teachers can meet new friends, gain new knowledge and become more successful in their career. The Center has the evaluation policy to encourage its staff members to participate in conferences or seminars.

\subsection{Participating in a network of teachers}

A good network of colleagues is very important for teachers' professional development. As shown in Table 1, about 64.7 percent of teachers participated in certain groups of professional development. Like in any other profession, networking is a good opportunity to build new relationships. For the past few years, the "CFL community" is an effective group of teachers who can exchange teaching ideas as well as problems. Recently, the Center also creates a group on Zalo and Facebook to update teaching schedules, share workload, introduce innovative 
teaching practices, or simply have fun with each other.

\subsection{Attending a qualification program}

Over half of the participants followed a qualification program, especially a master program for the past years. As a criterion of annual teacher evaluation, the Center has a policy to encourage teachers to upgrade their knowledge, at least with a master degree. For the past three years, the number of master holders has increased. If in 2015, 66 percent of teachers are bachelor degree holders and only 34 percent of them have graduate degrees, then currently 69.5 percent of teachers have master degrees.

\subsection{Participating in individual or collaborative research}

Research-led teaching or research-oriented teaching approach has gained increasing attention and become a global trend in education. Recently, the Center has a policy to encourage its staff to undertake action research or case study related to their teaching. As shown in Table 1, although 27 (52.9\%) out of 51 teachers have undertaken mini-research, almost half of teachers have not participated in any research. Those who conduct research generally are young teachers who have to complete their graduate programs.

\section{CONCLUSIONS AND SUGGESTIONS}

\subsection{Conclusions}

Professional development is a valuable tool for helping academic staff advance in their careers and feel more energized when they come to work every day. Education is an ever growing, ever changing field, and professional development should be institutional priority. Effective professional development programs allow teachers to learn new methodology, teaching techniques, and problem-solving skills. The results of the current study showed that workshops are the best strategy for professional development. Classroom observations and mentoring are also reported to have most positive effects on the academic staff's professional development. Research, as expected, is the activity in which teachers are the least confident. These results can be used for policy planning and making regarding staff development to enhance the institutional quality. An effective professional development program should establish and follow well-established standards to guide the design, evaluation, and funding of staff development. To be effective, academic staff's professional development requires thoughtful planning followed by careful implementation with feedback to ensure that the program responds to the staff's developmental needs. Also, academic administrators can improve the quality of professional development by engaging the staff members in planning, implementation and evaluation of professional development programs. From the findings, there are some important suggestions for both academic leaders and teachers.

\subsection{Suggestions}

\subsubsection{For academic leaders}

The commitment for staff development should start at the top. Academic leaders should serve as facilitators for successful professional development by keeping a persistent focus on continuous staff improvement. The leaders are expected to encourage and support all staff to take advantage of professional development. The leaders should create a culture of reflection and evaluation of teaching practice by encouraging academic staff to engage in peer support/observation of teaching and use methods of evaluation from a variety of sources such as student, peer, self to review and enhance their practice as relevant to their job.

Professional development should not be viewed as simply orientating new staff. Academic leaders should be aware of the medium-term career pathways of their staff to ensure that appropriate opportunities for professional development are provided. The leaders should regularly conduct needs analysis such as using information from staff surveys to identify areas of professional development. Data from these sources can help ensure that professional development programs are not relevant to work context and supports the areas of knowledge and skills.

The leaders should also identify and develop an academic team as mentors who are qualified to support teachers' learning in their areas of expertise. Learning from a more experienced colleague is an invaluable way to gain insight into an effective teaching. The leaders should provide sufficient financial supports to increase to increase opportunities for professional learning and collaboration. Professional development should be flexible and administrators should appropriately update expectations and requirements. The leaders also should consider performance monitoring as one of the main management processes which is used as a way to ensure that everyone in the institution conduct their duties to the best of their abilities. 
At the Center's context, professional development should be regular and mandatory. It is important to recognize that professional development takes time and commitment, and institutional leaders must be willing to ensure that staff members should have both the time and financial support they need to participate in their own learning.

\subsubsection{For teachers}

Professional development is often most beneficial when it uses a 'bottom-up' approach. Teachers should be responsible for identifying and suggesting learning opportunities to their managers based on their current job description and career aspirations. Every teacher may face unique classroom challenges, and teachers should have a choice about what or how they learn.

Academic staff members should be engaged in continuous learning to enhance their performance in their current roles. Teaching is a lifelong learning process, and the world is always changing, along with the curriculum and educational technology. An effective, successful teacher should be a continuous learner.

Teachers are expected to undertake a range of opportunities to enable them to update their knowledge and skills. In this modern, digital age, teachers need to be flexible and be able to adapt to changing situations. New technologies are developed every day that can change the way students learn, and the way teachers teach. Being able to adapt is a skill that very modern teacher must have.

The Center for Foreign Languages, Can Tho University is committed to providing staff members with the opportunity to develop capabilities and to participate in career development activities to assist teachers in meeting new demands in the time of knowledge extension and information sharing. The teaching profession and its development are fundamental and crucial to guaranteeing quality in teachers' performance and the Center's quality. A quality education system must be underpinned by quality teachers. An organized and efficient professional development program with supportive apparatuses will significantly assist an educational institution to retain the most valued teaching staff, not only the novice teachers but also those who have a lot of experience with the institution. If an institution is ca- pable to support all the staff in meeting their requirements then both, the staff members and the institution will get the long-term benefits.

\section{REFERENCES}

Blackwell, R. and Blackmore, P., 2003. Toward strategic staff development. Buckingham: Society for Research into Higher Education and Open University Press, 258 pages.

English Agenda, 2012. Going forward: Continuing professional development for English language teachers in the UK, accessed on 5 August 2019. Available from https://englishagenda.britishcouncil.org/sites/default/files/filefield_paths/b413_cpd_for_teachers_v2.pdf.

Gore, J., Lloyd, A., Smith, M., Bowe, J., Ellis, H., 2017. Effects of professional development on the quality of teaching: Results from a randomized controlled trial of quality teaching rounds. Teaching and Teacher Education. 68: 99-113.

Jan, H., 2017. Teacher of $21^{\text {st }}$ century: Characteristics and development. Research on Humanities and Social Sciences. 7(9): 50-54.

Jusuf, H., 2005. Improving teachers' aquality, a keyword for improving educational facing global challenges. The Turkish Online Journal of Educational Technology. 4(1): 33-37.

Marcelo, C., 2009. Professional development of teachers: Past and future. Educational Sciences Journal. 8(1): 5-20.

Mizell, H., 2010. Why professional development matters, accessed on 22 August 2019. Available from https://learningforward.org/wp-content/uploads/2017/08/professional-development-matters.pdf.

Nagoba, B. S., and Mantri, S. B., 2015. Role of teachers in quality enhancement in higher education. Journal of Krishna Institute of Medical Sciences University. 4(1): 177-182.

OECD (Organization for Economic Cooperation and Development), 2009. Creating Effective Teaching and Learning Environments: First Results from TALIS, accessed on 10 August 2019. Available from http://www.oecd.org/education/school/creatingeffectiveteachingandlearningenvironmentsfirstresultsfromtalis.htm.

Rowley, J., 1996. Motivation and academic staff in higher education. Quality assurance in Education. 4(3): 11-16.

World Bank, 1994. Higher Education: The lessons of experience, accessed on 31 July 2019. Available from http://documents.worldbank.org/curated/en/303461468328502540/Higher-educationthe-lessons-of-experience. 